\title{
Effectiveness of ozonated water in the reprocessing of blood dialyzers
}

\author{
Morian Lauana Miguelão Canada*, Ursulandrea Sanches Abelan, Renato Amaro Zangaro, \\ Dora Inês Kozusny-Andreani, Roseli de Fátima Custódio Yamazaki
}

\begin{abstract}
Introduction: Ozone is a potent antibacterial agent. Because ozone oxidizes organic material, it directly attacks microorganisms resulting in safe, fast and economical sterilization at low temperatures. This study evaluated the efficacy of ozonated water in the reprocessing of dialyzers obtained from a hemodialysis service in São José do Rio Preto. Methods: A total of 23 blood dialyzers were collected at the conclusion of the morning hemodialysis shift. The equipment was collected after the maximum number of reuses, with the last disinfection performed with purified water (obtained by reverse osmosis and subsequent reverse ultrafiltration). The number and species of microorganisms in the dialyzers were evaluated before and after treatment with ozonated water. The ozonation of sterile deionized water was achieved by direct contact between the water and the ozone generating equipment. Results: The mean number of microorganisms before sterilization was $1,47.10^{9}$ colony forming units per $\mathrm{ml}(\mathrm{CFU} / \mathrm{ml})$. After treatment with ozonated water, the number of microorganisms was 4,80.10 $\mathrm{CFU} / \mathrm{ml}$. Conclusion: Ozonated water is an effective decontaminant for most blood dialyzers.
\end{abstract}

Keywords Reprocessing, Hemodialysis, Ozone.

\section{Introduction}

Chronic renal failure (CRF) represents a public health problem in Brazil with high rates of morbidity and mortality. According to the Brazilian Society of Nephrology, there were 47,063 patients on dialysis in 2000, and an estimated 92,091 patients on dialysis in 2010 (Sesso et al., 2011).

There are several choices for renal replacement therapy, including drug therapy, continuous ambulatory peritoneal dialysis, automated peritoneal dialysis, intermittent peritoneal dialysis, hemodialysis and renal transplantation (Barros et al., 2006; Figueiredo, 2010; Martins and Cesariano, 2005). Specialists, together with their patients, consider the degree of renal deterioration, a nutritional assessment and social and psycho economic factors to determine the appropriate treatment choice

In hemodialysis, the blood is filtered, and undesirable substances are removed. The procedure consists of the transfer of solutes between the blood and the dialysis solution through an artificial semipermeable membrane (dialyzer or blood capillary). Solutes are transported by diffusion, ultrafiltration and convection (Barros et al., 2006; Lima and Santos, 2004).

Sustainability is important to hospitals because of the high rates of waste generation in healthcare. Reprocessing blood dialyzers decreases the production of solid health waste and is a common procedure in the United States. Reprocessing is practiced by more than $75 \%$ of the Institutes of Hemodialysis in the

*e-mail: mo miguelao@hotmail.com

Received: $0 \overline{3}$ September 2013 / Accepted: 05 May 2014
United States and saves the country over \$200 million annually (Okechukwu et al., 2000).

Dialyzer reuse is considered safe and effective for thousands of patients. This practice requires high-flux dialyzers, which are more expensive and durable. The reuse of dialyzers decreases the incidence of reactions attributed to first use, and allows dialysis treatment to be widely available (Cho et al., 2004; Miles and Friedman, 1997).

According to resolution $\mathrm{nr} 154$, after June $15^{\text {th }}$ 2004, dialyzers and arterial/venous lines may be used for the same client up to twelve times using manual reprocessing, or up to twenty times when using automatic reprocessing. Dialyzers and lines eligible for reuse should be chemically disinfected. Sodium hypochlorite $0.6 \%$, hydrogen peroxide (3\% or less) and mixtures of peracetic acid/peroxide hydrogen/ acetic acid are often used as disinfectants (Brasil, 2004; Riella, 2010).

Ozone is hypothesized to be a powerful sterilizing agent. It has excellent oxidant action, potent bactericidal effects after a few minutes of exposure and promotes a high-level of disinfection. It is a safe and fast technology, and an economical alternative for sterilization at low temperatures (Baysan et al., 2000; Bocci, 2005; Silva et al., 2009).

The present study evaluated the efficiency of ozonated water in the reprocessing of dialyzers from a hemodialysis service in São José do Rio Preto - SP. 


\section{Methods}

Dialyzers were obtained from a hemodialysis service in São José do Rio Preto-SP. A total of 23 blood dialyzers were collected between the $2^{\text {nd }}$ and $31^{\text {st }}$ of January, 2013. Dialyzers were obtained at the conclusion of the morning hemodialysis shift (Monday to Friday, representing $20 \%$ of the disposal of service). The dialyzers were manufactured by the Nipro Corporation (Osaka, Japan), and their structure was composed of polycarbonate, polyurethane and polyethylene terephthalate. The inner surface did not exceed $22 \mathrm{~mm}^{2}$, and the transmembrane pressure capacity was $500 \mathrm{mmHg}$. This equipment was being evaluated at the maximum number of reuses, according to the resolution RDC nr 154, June $15^{\text {th }}, 2004$ (Brasil, 2004). The last disinfection was performed with purified water (obtained by reverse osmosis followed by reverse ultrafiltration). After removing the dialyzers from the reuse room of the hemodialysis service, the equipment was placed in individual ice boxes and sent to the laboratory for analysis. The culture media used for the internal sample of dialyzers were Sabouraud-dextrose agar $\left(\right.$ OXOID $\left.^{\circledR}\right)$ lab-InterlabDistributor of Scientific Laboratories of São Paulo-SP and Trypticase soy agar (Imedia Laboratorius PVT limited ${ }^{\circledR}$ ) Mumbai, Maharashtra, Índia.). Dialyzers were evaluated for the presence and total number of mesophilic organisms and their species. The dialyzers were then subjected to internal treatment with ozonated water and the microbiological analysis was repeated. The Ozon \& Life ${ }^{\circledR}$ corona ozone generator was connected to the oxygen cylinder and used for the ozonation of sterile deionized water. Ozone was steadily produced by the machine and transported by a silicone tube to the diffuser at a rate of $2 \mathrm{ppm} / \mathrm{minL}$. The water was directly exposed to ozone for 3 minutes through the diffuser at a controlled temperature of $25^{\circ} \mathrm{C}$, and then used for the internal sterilization of the blood dialyzers. A system consisting of a bottle with a connector adapted to the dialyzer (Figure 1) was used to wash the internal compartments of the fibers with ozonated water. The ozonated water flowed for 10 minutes inside the dialyzers. The collection of the internal material of the dialyzers was performed in laminar flow (Pachane brand) with a micropipettor. A quantity of $0.1 \mathrm{~mL}$ was removed from the internal contents of the dialyzers and used for inoculation of Petri plates containing the previously described culture media distributed through sterile glass beads. The Petri dishes were incubated in a BOD incubator at $37{ }^{\circ} \mathrm{C}$ for $24-48$ hours to cultivate bacteria and yeast, and for two weeks to cultivate filamentous fungi. Microorganisms were quantified and expressed

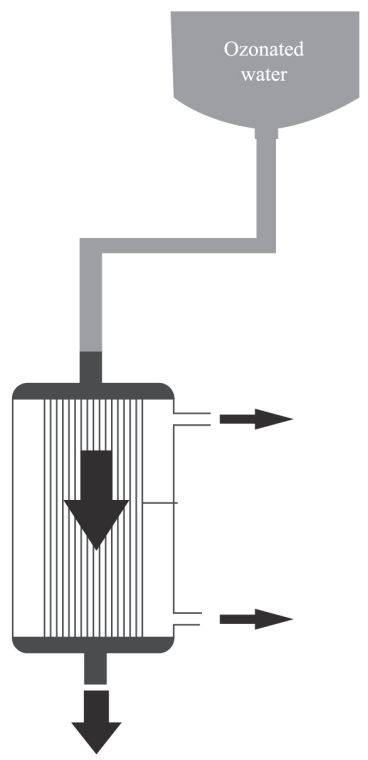

Figure 1. Model used for the reprocessing of dialyzers.

as colony forming units per $\mathrm{mL}(\mathrm{CFU} / \mathrm{mL})$. The morphology of the colonies was using Gram staining and observed by light microscopy. After staining, colonies were transferred to different agarized media to maintain pure cultures. Gram-positive bacteria were grown on Baird-Parker Agar $\left(\right.$ Oxoid $\left.^{\circledR}\right)$ with TSA medium, and Gram-negative bacteria were grown on Eosin Methylene Blue (EMB, Oxoid $\left.{ }^{\circledR}\right)$. Samples were incubated at $37^{\circ} \mathrm{C}$ for 24 hours. The yeasts were transferred to Sabouraud dextrose agar. This procedure was repeated three times before performing different biochemical tests.

Gram-negative bacteria were identified by the API20E system (Analytical Profile Index, BioMérieux $^{\circledR}$ ). Coagulase and catalase, $\mathrm{NaCl} 5 \%$, oxidase, novobiocin and DNAse tests were used for Gram-positive bacteria. Yeasts were grown on CHROMagar (Difco ${ }^{\circledR}$ ) and subsequently identified by germ tube formation, urease tests and fermentation of carbohydrates (maltose, sucrose, lactose, galactose, xylose and dextrose).

Data were analyzed by the Mann-Whitney nonparametric test and the chi-square test with 0.05 $(5 \%)$ probability. Minitab $15^{\circledR}$ software was used for statistical analysis.

\section{Results}

In total, 41 occurrences of microorganisms were verified in the blood dialyzers ( 34 before treatment with ozonated water, and seven after the treatment). Table 1 
shows the number and species of microorganisms found in the dialyzers before and after exposure to ozonated water. There was a significant presence of C. albicans in the evaluated dialyzers. Few bacteria were found, with the isolated species including Escherichia coli, Streptococcus sp, Micrococcus sp and Proteus mirabilis. Filamentous fungi were not isolated. Table 2 demonstrates significant differences in the total count of mesophilic microorganisms when comparing the dialyzers in relation to treatment with ozonated water $(\mathrm{P}<0.001)$.

\section{Discussion}

Improper maintenance of hemodialysis water systems and reprocessing of dialyzers may result in reactions in hemodialysis patients (Borges et al., 2007). The quality of dialysis fluids depends on complex systems with devices and procedures that allow for effective treatment. If the water is not treated properly, potentially harmful chemical or biological contaminants may be transferred to patients. This exposure may lead to the appearance of pyrogenic reactions and sepsis (Calderaro and Heller, 2001; Varo et al., 2007). Even after undergoing some treatment, the water may still be contaminated with microorganisms depending on the efficiency of the disinfection method used. Ineffective disinfection leads to biofilm formation in hemodialysis systems (Cappelli et al., 2006).

In the present study, microorganisms including Candida albicans, Escherichia Coli, Streptococcus $s p$, Micrococcus sp and Proteus mirabilis were

Table 1. Number and species of isolated microorganisms in 23 dialyzers before and after treatment with ozonated water in a hemodialysis service in São José do Rio Preto-SP, 2013.

\begin{tabular}{clc}
\hline Treatment & Microorganism & Quantity* \\
\hline Before & Candida albicans & 23 \\
$(\mathrm{n}=34)$ & Escherichia coli & 1 \\
& Streptococcus & 2 \\
& Micrococcus & 5 \\
& Proteus mirabilis & 3 \\
After & Candida albicans & 6 \\
$(\mathrm{n}=7)$ & Micrococcus & 1 \\
Total & & 41 \\
\hline *Number of dialyzers contaminated by the microbial species.
\end{tabular}

identified before the reprocessing of blood dialyzers with ozonated water. These colonies corresponded to 34 patients with Candida albicans and seven occurrences of Micrococus after dialysis treatment (Table 1). Studies show that approximately $90 \%$ of the bacteria isolated in hemodialysis water are Gramnegative. This bacteria multiplies rapidly, reaching concentrations greater than $10^{5} \mathrm{CFU} / \mathrm{ml}$ in less than 24 hours (Borges et al., 2007). Research has identified that the main microorganisms isolated in hospitals are Staplylococcus aureus, Streptococcus pneumoniae, Enterococcus, Pseudomonas sp, Escherichia coli and Candida albicans. The most common (95\%) etiological agent associated with urinary tract infections (UTI) in elderly women is Escherichia coli. In men, Proteus mirabilis is the most commonly identified microorganism in hospitalized patients and Escherichia coli in outpatients (Abelan et al., 2013; Corrêa and Montalvão, 2010; Silva et al., 2008).

This study verified that the investigated samples contained high microbial load prior to treatment with ozonated water (Table 2). The pretreatment median values of $\mathrm{CFU} / \mathrm{ml}$ were $2 \times 10^{9}$, and after disinfection with ozonated water, they were $0(p<0.001)$. Therefore, the ozonated water was effective in decontaminating blood dialyzers. Santos et al. (2007) compared ozone to peracetic acid in hydraulic circuits and hemodialysis machines. The average number of bacteria in the dialysis solution after peracetic acid treatment was $17 \mathrm{CFU} / \mathrm{ml}$, and it was $10 \mathrm{CFU} / \mathrm{ml}(\mathrm{p}<0.05)$ when using ozone.

In this study, after the dialyzers were exposed to ozonated water, there was total elimination of the following bacterial species: E. coli, Streptococcus and Proteus mirabilis. A small number of the species Microccus $s p$, remained in the dialyzer (Table 1). Prabakaran et al. (2012) also reported that E.coli was highly sensitive to ozone treatment. According to Bocci et al. (2009), the antimicrobial action of ozone results from the inhibition of the metabolic activity of microorganisms. Ozone is therefore capable of broad spectrum disinfection by destroying the viral DNA and acting in the formation of free radicals (Stübinger et al., 2006).

The incidence of fungal infections has increased considerably in hospital settings, and the species Candida albicans has become a predominant pathogen

Table 2. Total value of mesophilic microorganisms before and after exposure of the 23 blood dialyzers to ozonated water in a hemodialysis service in São José do Rio Preto-SP, 2013.

\begin{tabular}{ccccccc}
\hline Treatment & $\mathbf{N}$ & $\overline{\boldsymbol{x}} \pm \boldsymbol{s}$ & Md & Min & Max & P-value* \\
\hline Before & 23 & $1,47.10^{9} \pm 8,97.10^{8}$ & $2,00.10^{9}$ & $4,00.10^{1}$ & $2,00.10^{9}$ & $<0.001$ \\
After & 23 & $4,80.10^{1} \pm 1,55.10^{2}$ & 0.00 & 0.00 & $7,30.10^{2}$ & \\
\hline
\end{tabular}

*P-value relative to the Mann-Whitney test at $5 \%$ significance. 
for critically ill patients. Candida albicans results in high morbidity and mortality accounting for approximately $80 \%$ of documented hospital infections. Changes in host defense mechanisms are often the result of immunosuppression induced by medical procedures (Dignani et al., 2003; Hamill and Hollander, 1997; Penna, 1999). Several factors contribute to the virulence and pathogenicity of $C$. albicans including its ability to adhere to the epithelium and mucosa, the dimorphism that aids in tissue invasion, significant thermotolerance and its capacity to form biofilms (Ross et al., 2006).

In this study, the presence of Candida albicans in the 23 dialyzers evaluated prior to the disinfection was significant. After treatment with ozonated water, only six dialyzers were contaminated with $C$. albicans. However, a high reduction of CFU/mL (initially $2 \times 10^{9} \mathrm{CFU} / \mathrm{ml}$, Table 2) was found. Abelan et al. (2013) determined that a 15 minute application of ozonated water was capable of sterilizing nail pliers contaminated with $C$. albicans.

According to the resolution RDC nr 154, of June $15^{\text {th }} 2004$ (Brazil, 2004), the water used in preparing the solution for dialysis services must have its quality guaranteed at all stages of treatment, storage and distribution through the monitoring of microbiological and physico-chemical parameters. A quantity of up to $200 \mathrm{CFU} / \mathrm{ml}$ of heterotrophic bacteria is acceptable with the absence in $100 \mathrm{~mL}$ of fecal coliforms and $2 \mathrm{EU} / \mathrm{mL}$ of endotoxins. These standards are associated with the prevention of clinical complications arising from bacterial contamination of the dialysis fluid. In this study, there was one dialyzer contaminated by Escherichia coli (Table 1), and a high incidence of mesophilic microorganisms above the parameters accepted by legislation (Lonneman, 2010).

The correct use of ozone dissolved in water may be a safe, practical, inexpensive and effective method for removing bacteria and biofilms. Ozone has a high oxidative capacity, affecting enzymatic systems and cell membranes. The oxidation causes cell lysis and prevents bacterial growth (Santos et al., 2007; Silva et al., 2009).

Thanomsub et al. (2002) found that the ozone treatment was able to modify and destroy the structure of Gram-positive and Gram-negative bacteria. After 30 minutes of ozone exposure, the number of bacteria in cultures of $10^{3}, 10^{4}$, and $10^{5} \mathrm{CFU} / \mathrm{ml}$ decreased. However, at higher bacterial loads (concentrations of $10^{6}$ and $10^{7} \mathrm{CFU} / \mathrm{ml}$ ), there was a gradual decline in the survival of the cells, but the ozone was not effective against all bacterial cells even after a longer treatment period (150 minutes). Adequate concentrations of ozone can effectively result in antimicrobial activity by destroying the bacterial cell membrane and resulting in intracellular leakage and cell lysis (Thanomsub et al., 2002).

Currently, dialysis treatment seeks to reverse uremic problems by using modern machines for cardiopulmonary bypass and a filter that matches the blood dialyzer. This treatment leads to a decreased risk of morbidity and improves the quality of life and social reintegration of these patients. The use of ozonated water as the sterilizing agent for reprocessing dialyzers requires additional research. It is an innovative practice that is straightforward, inexpensive and benefits patients, the health team and the environment.

This study determined that ozonated water can effectively decontaminate most blood dialyzers resulting in a total elimination of microorganisms. The average microbial load before sterilization was $1,47.10^{9}$ colony forming units per $\mathrm{ml}(\mathrm{CFU} / \mathrm{ml})$. After treatment with ozonated water, the number of microorganisms was $4,80.10^{1} \mathrm{CFU} / \mathrm{ml}$. These results suggest that this biocide can be used in the control of pathogenic micro-organisms in health care, but should be considered microbial species involved.

\section{Acknowledgements}

We thank the Centro Universitário de São José do Rio Preto-SP (Unirp) and the Universidade Camilo Castelo Branco (UNICASTELO) for their support.

\section{References}

Abelan US, Zangaro RA, Kozusny-Andreani DI. Avaliação da atividade antimicrobiana da água ozonizada em alicates utilizados por manicures. In: Anais do I Encontro de Pós Graduação e Iniciação Científica UNICASTELO; 2013; Fernandópolis.

Barros EM, Manfro RC, Thomé FS, Goncalves LFS. Nefrologia: rotinas, diagnóstico e tratamento. 3. ed. Porto Alegre: Artmed; 2006

Baysan A, Whiley RA, Lynch E. Antimicrobial effect of a novel ozone-generation device on micro-organisms associated with primary root carious lesions in vitro. Caries Research. 2000; 34(6):498-501. PMid:11093025. http:// dx.doi.org/10.1159/000016630

Bocci VA. Ozone: a new medical drug. 2nd ed. Springer: The Netherlands; 2005. PMCid:PMC2361561

Bocci VA, Borelli E, Travagli V, Zanardi I. The ozone paradox: ozone was a Strong oxidant as well as a medical drug. Medicinal Research Reviews. 2009; 29(4):646-82. PMid:19260079. http://dx.doi.org/10.1002/med.20150

Borges CR, Lascowski KMS, Filho NR, Pelayo JS. Microbiological quality of water and dialysate in a hemodialysis unit in Ponta Grossa-PR, Brazil. Journal of Applied Microbiology. 2007; 103(5):1791-7. PMid:17953589. http://dx.doi.org/10.1111/j.1365-2672.2007.03431.x

Brasil. Agência Nacional de Vigilância Sanitária - Anvisa. Resolução RDC no 154 de 15 de junho de 2004. Estabelece 
o regulamento técnico para o funcionamento dos serviços de diálise. Diário Oficial da União, Brasília, 17 jun. 2004.

Calderaro RVV, Heller L. Surto de reações hemolíticas associado a residuais de cloro e cloraminas na água de hemodiálise. Revista de Saúde Pública. 2001; 35(5):4816. PMid:11723521. http://dx.doi.org/10.1590/S003489102001000500012

Cappelli G, Riccardi M, Perrone S, Bondi M, Ligabue G, Albertazzi, A. Water treatment and monitor disinfection. Hemodialysis International. 2006; 10(1):13-8. PMid:16441861. http://dx.doi.org/10.1111/j.1542-4758.2006.01184.x

Corrêa EF, Montalvão ER. Infecções do trato urinário em geriatria. Estudos. 2010; 37(7):625-35.

Cho HK, Shin GT, Kim H. Status of dialyser reuse in Korea. Nephrology. 2004; 9(4):212-6. PMid:15363052. http:// dx.doi.org/10.1111/j.1440-1797.2004.00263.x

Dignani MC, Solomkin, JS, Anaissie E. Candida. In: Anaissi E, Mc Ginnis MR, Pfaller MA, editors. Medical mycology. Filadélfia: Churchill Livingstone; 2003. p. 195-239.

Figueiredo NM. Práticas de enfermagem: ensinando a cuidar de clientes em situações clínicas e cirúrgicas. 1. ed. São Paulo: Yendis; 2010.

Lima EX, Santos I. Atualização em enfermagem em nefrologia. Rio de Janeiro: SOBEN; 2004.

Lonneman G. The quality of dialysate: an integrated approach. Kidney International. 2010; 58:112-9. http:// dx.doi.org/10.1046/j.1523-1755.2000.07614.x

Hamill RJ, Hollander H. Infectious diseases: mycotic. In: Tierney Jr LM, McPhee SJ, Papadakis MA, editors. Connecticut: Appleton \& Lange; 1997. p 1356-7.

Martins MRI, Cesariano CB. Qualidade de vida de pessoas com doença renal crônica em tratamento hemodialítico. Revista Latino-Americano Enfermagem. 2005; 13(5):670-6. http://dx.doi.org/10.1590/S0104-11692005000500010

Miles AMV, Friedman EA. A review of hemodialyzer reuse. Seminars in Dialysis. 1997; 10(1):32-7. PMid:19140862. http://dx.doi.org/10.1111/j.1525-139X.1997.tb00457.x

Okechukwu CN, Orzol SM, Held PJ, Pereira BJ, Agodoa LY, Wolfe RA, Port FK. Characteristics and Treatment of Patients Not Reusing Dialyzers in Reuse Units. American Journal of Kidney Diseases. 2000; 36(5):991-9. PMid:11054356. http://dx.doi.org/10.1053/ajkd.2000.19101
Prabakaran M, Tamil S, Merinal S, Panneerselvam A. Effect of ozonation on pathogenic bactéria. Advances in Applied Science Research. 2012; 3(1):299-302.

Penna GO. Doenças infecciosas e parasitárias: aspectos clínicos, de vigilância epidemiológica e de controle; guia de bolso. Brasília: Ministério da Saúde; 1999. PMCid:PMC1727695

Riella MC. Princípios de nefrologia e distúrbios hidroeletroliticos. 5. ed. Rio de Janeiro: Guanabara; 2010.

Ross C, Quesada RMB, Girardello R, Rogeri LMS, Calixto LA, Pelayo JS. Análise microbiológica de pontas de cateteres venosos centrais provenientes de pacientes internados no Hospital Universitário da Universidade Estadual de Londrina. Semina: Ciências Biológicas e da Saúde. 2006; 27(2):117-23. http://dx.doi.org/10.5433/1679-0367.2006v27n2p117

Santos F, Biernat JC, Santos AMG, Souza MELS, Raubach AS, Demin MSS. Desinfecção de máquinas de hemodiálise com ozônio. Jornal Brasileiro de Nefrologia. 2007; 24(1):14-8.

Sesso R, Lopes AA, Thomé FS, Lugon JR, Santos DN. Relatório do censo brasileiro de diálise de 2010. Jornal Brasileiro de Nefrologia. 2011; 33(4):442-7. PMid:22189808. http://dx.doi.org/10.1590/S0101-28002011000400009

Silva J, Ferreira S, Costa E, Resende A, Ramos MH. Agentes etiológicos e contaminantes em hemoculturas. Revista Portuguesa de Ciências Biomédicas. 2008; 111(3):18-21.

Silva RA, Garotti JER, Silva RSB, Navarini A, Pacheco AM Jr. Analysis of the bactericidal effect of ozone pneumoperitoneum. Acta Cirurgica Brasileira. 2009; 24(2):124-7. PMid:19377781. http://dx.doi.org/10.1590/S0102-86502009000200009

Stübinger S, Saber R, Fillipi. A. The use of ozone in dentistry and maxillofacial surgery: a review. Quintessence International. 2006; 37(50):353-9. PMid:16683682

Thanomsub B, Anupunpisit V, Chanphetch T. Effects of ozone treatment on cell growth and ultrastructural changes in bacteria. Journal of General and Applied Microbiology. 2002; 48(4):193-9. PMid:12469318. http:// dx.doi.org/10.2323/jgam.48.193

Varo SD, Martins CHG, Cardoso MJO, Sartori FG, Montanari $\mathrm{LB}$, Goncalves RHP. Isolamento de fungos filamentosos em água utilizada em uma unidade de hemodiálise. Revista da Sociedade Brasileira de Medicina Tropical. 2007; 40(3):32631. PMid:17653470. http://dx.doi.org/10.1590/S003786822007000300015

\footnotetext{
Authors

Morian Lauana Miguelão Canada*, Ursulandrea Sanches Abelan

Centro Universitário de Rio Preto - UNIRP, Rua Ivete Gabriel Atique, 45, Boa Vista, CEP 15025-400, São José do Rio Preto, SP, Brasil.
}

Morian Lauana Miguelão Canada, Renato Amaro Zangaro, Dora Inês Kozusny-Andreani Universidade Camilo Castelo Branco - UNICASTELO, São José dos Campos, SP, Brasil.

Roseli de Fátima Custódio Yamazaki

Institute of Urology and Nephrology - IUN, São José do Rio Preto, SP, Brasil. 